\title{
Development of the Computer Graphics Management System Using Text of Natural Language
}

\author{
Al Salaimeh S.
}

\author{
Aqaba University of Technology, 79 Wasfi al-Tal St., Aqaba, Jordan
}

\author{
Article info: \\ Paper received: \\ The final version of the paper received: \\ Paper accepted online:
}

June 5, 2018

August 24, 2018

August 30, 2018

\author{
"Corresponding Author's Address: \\ ssalaimeh@aut.edu.jo
}

\begin{abstract}
The computer has been an integral part of our life. We cannot imagine complicated mathematical and technological calculation without using computer, but we are at this stage in the development of computing systems, when is not enough computer obedience. We needed an assistant. In this paper, we can see the predicate presentation of the text of the natural language personal computer is able to understand person and obey his command. As for the scope of this method of representing natural language text, it is seen the first time that is the use spectrum is very large; firstly, it can be used for research and educational purposes, as well as to study algebra of predicates. Secondly, use as an assistant in the word a user with a computer (is a good addition to the programs engaged in speech recognition). Thirdly, in the regions associated with artificial intelligence.
\end{abstract}

Keywords: predicate, natural language, mathematical calculation, human speech, artificial intelligent.

\section{Introduction}

Since of this century, the human way of life has undergone serious changes. The computer has been an integral part of our life. We cannot imagine complicated mathematical and technological calculation without using computer, but we are at this stage in the development of computing systems, when is not enough computer obedience. We needed an assistant.

So that computer can carry out nonstandard tasks, it is necessary to teach to thing and communicate with person, in other words. Technical systems, mechanized mental work, got the name of artificial intelligence systems [1-4].

\section{Research Methodology}

One of the tasks of the artificial intelligence is developing systematic methods for translating the meaning of human speech into the language of predicate algebra. Make sense in the form of concepts into computer. But, how it can be done? What is the meaning of the utterance? It is not difficult to answer it. As is known, the meaning of utterance is a function of the dependence of variables of this statement. It remains only to find the text of the natural language object variable. We will consider finding object variable in the text of natural language in comparison with the detection of these variable in mathematical statements.

Consider an example, mathematical statement $(x+y=z)$, where $x, y, z-$ object variables by which and in this case is variables definition on set $N=\{0,1,2, \ldots\}$ all nonnegative integers, in this form the mathematical statement is not true, not false. But if you imagine this expression as a function $\xi=f(x, y, z)$, where $f-$ function that returns true or false mathematical expression turns into a true function, since the function $\xi$ indicates the truth of the mathematical expression. So, the meaning of a mathematical statement is a predicate $\xi=f\left(x_{1}, x_{2}, \ldots\right.$, $x_{n}$ ) representing the dependence of the true of a variable $\xi$ on $n$ subject variables $x_{1}, x_{2}, \ldots, x_{n}$ of this utterance.

We have consider, what is the meaning of the mathematical statement. Now, guided by hypothesis of a close relationship of natural and mathematical language, suppose, that such an interpretation of the meaning apply and to assumption of natural language [3].

The text of the natural language consists of word and the interrelations between them. We will leave the 
relationship for now, get special attention to words. Single words, from which a proposal is drawn up, we will consider as the basic elements of linguistics algebra. What do individual words mean? Suppose, that the express some predicate.

It is not difficult to see, what it is really. Let us take a word, for example: the word cube. Enter object variable $x$. turn to a person and we use it as a test subject, it is easy to see what is carrier of predicate. Expressed in word cube, really showing the subject a variety of subjects $x$ from any set A asking him, is it the subject $x$ cube? If $x$ is a cube, then theanswer is truth, otherwise false.

By it is behaviour, the subject is implemented by some predicate, dependent on $\mathrm{x}$ and defined on the set A. we write down it is types cube(x). it plays the role of the elementary formula of linguistics algebra. The word cube serves as predicate name, reproducible subjects. So, the introduced elementary predicates can be formed by means of Boolean operations; “_“, “^”, " $"$ " more difficult predicates: cub _or ellipse $(x)=$ cub $(x)^{\vee}$ ellipse $(x)$; $\_$cub $(x)=\mathrm{No}_{-} \operatorname{cub}(x)$; cub $(x)^{\wedge}$ ellipse $(y)=$ cub ${ }_{-}$and ellipse $(x, y)$. In the latter case, it is no longer one subject $x$, cube, a second one is ellipse, we see, that language uses negations as basic, disjunction and conjunctive, linguistic algebra refers to class of Boolean algebra [5-9].

Formalization of the text is subject to situational suggestions. For example: (in cube there is an ellipse). The relationship between objects cube and the ellipse is described_stand on $(x, y)$, it can be subjected to dismemberment. We introduce predicate stand _ $(y)$, understandable in the sense of an (object $y$ stand) a predicate on $(y, x)$, corresponding to utterance (subject $y$ situated on subject $x$ ), it is clear that the predicate stand _ on $(y, x)$ and stand $y^{\wedge}$ on $(y, x)$ match. It allows further splitting and predicate stand $(y)$. It can be represented as a conjunction predicates present time (y) and stand $(y)$. The first predicate means: "subject $y$ it is observed at the current time" second one: "subject $y$ presence is a state of standing" (irrespective of time).

Combining the conjunction of introduced predicates, we write the sentence in question in the following form. Cube $(x)^{\wedge}$ ellipse $(y)$ present _time $(y)$ stand $(y)$ ${ }^{\wedge}$ on $(y, x)$, we will not move further in the analysis of the semantic structure of this statement. To do this, it will be necessary to penetrate onto the semantic structure of words "cube" "and" "ellipse" “," "present" "time" "stand" "and" "on". For this you can refer to the explanatory dictionary, express the meaning of each of these word using the given in its different, the roles of which are phrases, made up of other words. When will this process end, you need to collect words, remaining not expression, and tie them to each other of utterances system bearers of the natural language as true. The utterances system performs the role of analysis in the system of axiom. Defining the primary concepts of mathematics. In the language it abstractly defines the meaning of the word, which cannot express using direct definition through other words. Above we demonstrate the subdivision of the verb, but the same division is allowed and nouns (object).
For example, the word cubes. These items consist of faces, which in turn consist of a set of points, united in the face. It means that if we denote all faces of the cube as:

face $1(x)$, face $2(x), \ldots$, face $6(x)$, then cube $\overline{(x)}=$ face $11 \overline{(x)} \wedge$ face $2(x) \wedge{ }^{\wedge}{ }^{\wedge}$ face $6(x)$, and each side can be represented in the following form: face $1(x)=$ point $\_11_{-} 1(x)^{\wedge}$ point $1_{-} 2(x) \wedge \ldots$ $\ldots{ }^{\wedge}$ point ${ }_{-}{ }_{-} n(x)$, face $2(x)=$ point ${ }_{-}{ }_{-} 1(x)^{\wedge}$ point $-2-2^{-}(x)^{\wedge} \ldots{ }^{\wedge}$ point $-2-\mathrm{n}(x), \ldots$ ..., face $6-\overline{(x)}=$ point ${ }_{-} 6(x) \wedge$ point $\overline{6}_{-} 2(x) \wedge$... $\ldots{ }^{\wedge}$ point $\_6{ }_{-} n(x)$.

\section{Results}

It can be shown, that almost all elements of the text of natural language can be divided into more primitive predicate, it means, that having identified all elementary predicates of the text there is natural language. We can express any situation with a semantic expression. Up to this point, we have considered the text there is a written natural language in terms of view of understanding the computer.

But for interaction IBM and human need computer management. For this purpose predicates of action, which unlike ordinary predicates, performs some kind of action and return of truth, if the specified action was successful, and false if not? Example: predicate highlight $(x)$. This predicate object, highlight (cube $(x))$, then the predicate of the action is checked for truth.

Predicate cub $(x)$ and if the subject cube exists, so the predicate highlight this subject. As you see, the predicate of action being given another predicate, which take on the function of checking for the presence of the environment of the object, of course, the possibility of applying a predicate is not ruled out in form highlight $(\mathrm{x})$, but in this case complexity of the fulfillment of the predicate is doubled (check for presence of the object $x$ among the selection of the object if it exists). The first cases are preferable, since at many levels of testing of action predicates the perform duplicate functions (check for existence of object among) example: move (highlight (cube $(x))$ )).

Action predicate are also subject to dismemberment, for example: a cube is drawn on the screen of the monitor, the user givers the command move (cube $(x)$ ). This expression will correspond to the structure of predicates, draw "recount coordinates (erase (cube $(x)$ )", this partitioning of the action predicate result from the specifics of the display of objects on the monitor. Also its possible to note, what happens when objects are dismembered as cube, the predicate of action acts to dismemberment, $\operatorname{draw}(\operatorname{cube}(x))=$ $\operatorname{draw}($ edge_(x) $) \wedge \operatorname{draw}($ edge_2 $(x)) \wedge \ldots \wedge$ $\operatorname{draw}\left(\right.$ edge $\left._{6} 6(x)\right)=\operatorname{draw}\left(\right.$ point $\left.1 \_1(x)\right) \wedge \ldots \wedge$ draw(point 1 - $n(x))$

$\operatorname{draw}\left(\right.$ point_2_1(x)) ${ }^{\wedge} \ldots{ }^{\wedge} \operatorname{draw}($ point_2_2 $(x)){ }^{\wedge} \ldots$ $\ldots \wedge \operatorname{draw}\left(\overline{p o i n t} \_6 \_1(x)\right)^{\wedge} \ldots \wedge \operatorname{draw}($ point_6_ $n(x))$. 


\section{Conclusions}

Summing up, we can say that thanks to predicate presentation of the text of the natural language personal computer is able to understand person and obey his command.

As for the scope of this method of representing natural language text, it is seen the first time that is the use spectrum is very large; firstly, it can be used for educational purposes to study algebra of predicates.

Secondly, use as an assistant in the word a user with a computer (is a good addition to the programs engaged in speech recognition).

Thirdly, in the regions associated with artificial intelligence and so on.

\title{
References
}

1. Ohajianya, A. C., Abumere, O. E., Owate, I. O., \& Osarolube, E. (2014). Erratic Power Supply in Nigeria: Causes and Solutions. International Journal of Engineering Science Invention, Vol. 3, No. 7, pp. 51-55.

2. Al Salaimeh, S., \& Pushkarev, A. N. (2011). Preliminary assessment for the effectiveness of the principles of logistics information management system. International Journal of Computer Science and Telecommunications, Vol. 2 , Issue 9.

3. Manning, C., \& Schütze, H. (2009). Foundations of Statistical Natural Language Processing, MIT Press, Cambridge.

4. Bird, S., Klein, E., \& Loper, E. (2009). Natural Language Processing with Python: Analyzing Text with the Natural Language Toolkit, O'Reilly Media.

5. Batiha, K., Al Salaimeh, S., \& Besoul, K. (2006). Digital Art and Design, Leonardo Journal of Science, pp. 1-8.

6. Al Salaimeh, S., \& Jabber, H. (2008). Weights Adjustment Neural Networks. European Journal of Scientific Research, Vol. 21, No. 2, pp. 314-318.

7. Al Salaimeh, S. Quality Assurance of Logistics Information System. American Journal of Scientific Research, Issue 1, pp 34-36.

8. Al Salaimeh, S., Makadmeh, Z., Avramenko, V. P., \& Shtangee, S. V. (2012). Optimal Resource Allocation under Bad Compatibility of Functional Limitations. International Journal of Computer Science and Technology, Vol. 3, Issue 1.

9. Al-Shatnawi, A. M., Zawaideh, F., Al Salaimeh, S., \& Khairuddin, O. (2011). Offline Arabic Text Recognition - An Overview. World of Computer Science and Information Technology Journal, Vol. 1, No. 5, pp. 184-192.

\section{Розроблення системи керування комп'ютерною графікою з використанням тексту природної мови}

\author{
Аль Салаймех С.
}

Технологічний університет м. Акаба, вул. Васфі аль-Тал 18, м. Акаба, Йорданія

\begin{abstract}
Анотація. Без комп'ютера як невід'ємної частини життя людства неможливо уявити складний математичний i технологічний розрахунок сучасних систем. Проте, на даному етапі розвивитку обчислювальних системи недостатньо комп'ютерного грамотності без відповідного програмного супроводу. У зв'язку із вищезазначеним, у статті викладено текст природної мови персонального комп'ютера, здатного зрозуміти людину і виконувати його команди. Стосовно обсягу запропонованого підходу, пов'язаного із поданням тексту природної мови, то показано різноманітний спектр іiї використання, по-перше, для наукових $\mathrm{i}$ освітніх цілей та вивчення алгебри предикатів. По-друге, даний підхід може бути використаний як помічник у зв'язку користувача із комп'ютером шляхом створення відповідних додатків до програмного забезпечення, у тому числі для розпізнаванням мови. По-третє, така методика може бути використана в областях, пов'язаних із створенням і застосуванням систем штучного інтелекту.
\end{abstract}

Ключові слова: предикат, природна мова, математичний розрахунок, людське мова, штучний інтелект. 